\title{
Adult mouse intrahepatic biliary epithelial cells induced in vitro to become insulin-producing cells
}

\author{
Masaki Nagaya $^{1,2}$, Hitoshi Katsuta ${ }^{1,2}$, Hideaki Kaneto ${ }^{3}$, Susan Bonner-Weir ${ }^{1,2}$ and Gordon C Weir ${ }^{1,2}$ \\ ${ }^{1}$ Research Division, Section on Islet Transplantation and Cell Biology, Joslin Diabetes Center, One Joslin Place, Boston, Massachusetts 02215, USA \\ ${ }^{2}$ Department of Medicine, Harvard Medical School, Boston, Massachusetts 02215, USA \\ ${ }^{3}$ Department of Internal Medicine and Therapeutics, Osaka University Graduate School of Medicine, 2-2 Yamadaoka, Suita, Osaka 565-0871, Japan \\ (Correspondence should be addressed to G C Weir; Email: gordon.weir@joslin.harvard.edu)
}

\begin{abstract}
Transdifferentiation of cells from a patient's own liver into pancreatic $\beta$-cells could be useful for $\beta$-cell replacement. We hypothesized that intrahepatic biliary epithelial cells (IHBECs) could become a new source of insulin-producing cells. IHBECs isolated from adult mice were expanded using our novel culture method termed, collagen-embedded floating culture method (CEFCM). With CEFCM, IHBECs formed three-dimensional ductal cysts and rapidly expanded their number by about 15 -fold within 2 weeks. Over $90 \%$ of cells were positive for cytokeratin 7 and 19. At day 14, IHBECs were transfected with adenoviral (Ad)- pancreas duodenum homeobox $1(P d x-1)$, NeuroD or $P d x-1 / V P 16$. After 7 additional days in serum- and insulin-free differentiation medium (DM), cell phenotypes were determined by RT-PCR, immunostaining and ELISA for insulin. In DM control IHBECs started to express some endocrine progenitor
\end{abstract}

genes (Neurog3, NeuroD, Nkx6.1, and $P d x-1$ ) but lacked insulin gene (Ins) mRNA. Transduced expression of PDX-1, NEUROD or PDX-1/VP16 led to expression of not only INS but also GLUT2 and prohormone convertase 1 and 2 . About 3\% of 4000 cells counted in PDX-1/VP16 transduced cultures stained strongly for C-peptide suggesting that a subpopulation may have the capacity for differentiation. Transduced cells released insulin (Ad-PDX-1 $0 \cdot 08 \pm 0 \cdot 05$, Ad-NEUROD $0 \cdot 33 \pm 0 \cdot 09$, Ad-PDX-1/VP16 $0 \cdot 37 \pm$ $0 \cdot 14 \mathrm{ng} / 1 \times 10^{5}$ cells after $48 \mathrm{~h}$ in culture). IHBECs can be markedly expanded, and then with molecular manipulation a subpopulation of these cells can differentiate towards a $\beta$-cell phenotype. This approach may lead to a new source of $\beta$-cells that can be used for transplantation in diabetes.

Journal of Endocrinology (2009) 201, 37-47

\section{Introduction}

There is great hope that transplantation of insulin-producing cells will be a cure-equivalent for type 1 diabetes (Shapiro et al. 2000, Ricordi \& Strom 2004), however, two major challenges remain: the shortage of available tissue and the need for immunosuppressive drugs. To resolve the first problem, efforts are underway to produce sufficient quantities of $\beta$-cells for transplantation (Bonner-Weir \& Weir 2005). Promising strategies include differentiation of embryonic stem cells (Kroon et al. 2008), conversion of either pancreatic adult stem/progenitor cells (Bonner-Weir et al. 2000), expansion of existing $\beta$-cells (Gershengorn et al. 2004), and xenotransplantation (Cardona et al. 2006, Hering et al. 2006). Transdifferentiation of cells from a patient's own tissue into pancreatic $\beta$-cells could address one obstacle of islet transplantation. This tissue could be obtained from a diabetic individual by endoscopic surgery, followed by in vitro expansion and differentiation into insulin-producing cells for subsequent autologous transplantation. Some researchers have pursued transdifferentiation using liver tissue both in vivo and in vitro (Ferber et al. 2000, Yang et al. 2002, Kojima et al. 2003, Sapir et al. 2005, Zalzman et al. 2005, Tang et al. 2006). The advantage of the liver is that both liver and pancreas develop embryologically from very similar pathways via the foregut endoderm (Wilson et al. 2003, Lemaigre \& Zaret 2004, Zaret 2008). Ectopic expression of NEUROD and PDX-1 has been found to promote the differentiation of liver towards pancreas (Ferber et al. 2000, Kojima et al. 2003, Sapir et al. 2005, Zalzman et al. 2005). Among the cell populations in the liver, the bile duct epithelium seems to have considerable promise as a new source of insulin-producing cells. It is clear that $\beta$-cells can exist surrounding the common bile duct of the liver (Sumazaki et al. 2004, Dutton et al. 2007), but the use of extrahepatic duct cells is problematic because the removal of sufficient amounts of tissue would be very dangerous (Antolovic et al. 2007). Oval cells are considered to be transit-amplifying hepatic progenitor cells (Factor et al. 1994, Yang et al. 2002, Kofman et al. 2005) and it has also been suggested that they can be precursors of insulin producing cells (Yang et al. 2002). However, they only appear in 
response to several types of pathologic liver injury (Factor et al. 1994, Kofman et al. 2005).

We focused our attention on intrahepatic biliary epithelial cells (IHBECs) for the following reasons: 1) A considerable amount of liver tissue can be surgically removed without much difficulty. 2) Liver has considerable capacity for regeneration (Michalopoulos \& DeFrances 1997). 3) IHBECs can serve as progenitors in response to certain stimuli; this can be shown in biliary ductules and even in the normal liver (Nagaya et al. 2006). We used normal liver for this study; therefore, there is little chance that oval cells were included in the preparation.

Cells were transduced with adenoviruses (Ad) expressing the transcription factors pancreas duodenum homeobox 1 (PDX-1), NEUROD, or PDX-1/VP16. PDX-1 plays a crucial role in pancreatic development (Jonsson et al. 1994), B-cell differentiation (Ferber et al. 2000, Sapir et al. 2005, Zalzman et al. 2005, Noguchi et al. 2006), and the maintenance of normal B-cell function (Ahlgren et al. 1998). PDX-1 overexpression in pancreatic ductal cells (Noguchi et al. 2006) or the liver (Ferber et al. 2000, Sapir et al. 2005, Zalzman et al. 2005), has been found to promote insulin gene expression. NEUROD is important for regulating insulin gene transcription and for the terminal differentiation of islet cells (Chae et al. 2004). In NeuroD gene targeting experiments, the combination of NeuroD and betacellulin selectively induced islet related genes in the liver (Kojima et al. 2003). PDX-1/VP16, a fusion protein of PDX-1 and the activating domain of the viral VP16 transcription factor, can markedly increase insulin biosynthesis and induce various pancreas-related markers in the liver and ameliorate glucose tolerance of streptozotocininduced diabetic mice (Kaneto et al. 2005).

Herein, we demonstrated that a meaningful amount of transdifferentiation has taken place from IHBECs through the use of these transcriptional factors. The cells can express proteins characteristic of $\beta$-cells and secrete insulin.

\section{Materials and Methods}

\section{Animals and surgery}

Adult 8 week old male C57/BL6 mice were obtained from Taconic Farms (Germantown, NY, USA). All animals were bred and maintained under specific pathogen-free conditions. Joslin Diabetes Center housing and husbandry guidelines were adapted from requirements in the Animal Welfare Act and the Guide for the Care and Use of Laboratory Animals in accordance with National Institutes of Health guidelines.

\section{Isolation and culture of IHBECs}

To isolate the IHBECs, a two-step liver perfusion was performed (Nagaya et al. 2006). The perfused liver was removed and hepatocytes were selectively removed by forcing them with gentle pressure through an incision in the liver capsule. Then, the remnant containing the intact biliary tree was shaken in the flask with Hanks solution for $5 \mathrm{~min}$ and washed several times. This treatment serves to remove residual hepatic parenchymal cells from biliary tissue fragments. The remnant tissues were collected and minced, transferred into a flask, and then treated with $0.02 \%$ soybean trypsin inhibitor (Gibco, Invitrogen Corporation) and 0.04\% collagenase solution (collagenase D, Roche) for $7 \mathrm{~min}$. The digested tissues were suspended in DMEM (Gibco) with 10\% FBS and $100 \mathrm{mg} / 1$ penicillin and $100 \mathrm{mg} / 1$ streptomycin, and centrifuged at $150 \mathrm{~g}$ for $1.5 \mathrm{~min}$. The pellet was resuspended in the medium, filtered sequentially through $250,100,40 \mu \mathrm{m}$ nylon mesh; small cell aggregates on the $40 \mu \mathrm{m}$ mesh were retrieved. Essentially, pure isolate of biliary tissue were obtained. Typical recovery was $1 \times 10^{5}$ viable cells with essentially pure biliary tissue obtained.

\section{Collagen-embedded floating culture method}

Cells were suspended in DMEM/F12 (Gibco) on ice containing $0.3 \mathrm{mg} / \mathrm{ml}$ collagen (Collagen type I rat tail, Becton Dickenson (BD), Franklin Lakes, NJ, USA). Then $1 \cdot 0 \times 10^{4}$ cells $/ \mathrm{ml}$ per well were plated in 12 -well dishes. The collagen-containing aggregates were allowed to solidify at $37^{\circ} \mathrm{C}$ for $2 \mathrm{~h}$; media was then changed to DMEM/F12 supplemented with 5\% FBS, 5\% NuSerum IV (BD), $0.5 \mu \mathrm{g} / \mathrm{ml}$ insulin-transferrin-sodium selenite (Gibco), $10 \mathrm{mmol} / 1$ nicotinamide, $1 \mathrm{mmol} / 1$ ascorbic acid 2-phosphate, $10^{-7} \mathrm{M}$ dexamethasone (Sigma-Aldrich Corp.), $10 \mathrm{ng} / \mathrm{ml}$ EGF (Fitzgerald Industries International, Inc., Concord, MA, USA), $10 \mathrm{ng} / \mathrm{ml}$ HGF (R\&D, Minneapolis, MN, USA) $4 \mu \mathrm{g} / \mathrm{ml}$ forskolin (Calbiochem, San Diego, CA, USA), and $3.4 \mu \mathrm{g} / \mathrm{ml} \mathrm{3,3,5-triiodo-L-thyromine} \mathrm{(Calbiochem).} \mathrm{This}$ medium is a modification of that described by Alpini et al. (2003), which we term growth medium (GM); it was changed every 2 days. With culture, the collagen gel (CG) containing the aggregates gradually contracted as shown in Fig. 2.

\section{Monolayer culture for IHBECs}

After 14 days in collagen-embedded floating culture method (CEFCM) culture, the aggregates were washed in $\mathrm{Ca}^{2+}$-free HEPES-buffered saline, then a $0 \cdot 1 \%$ collagenase solution, for $10 \mathrm{~min}$ to dissolve the CG and release the aggregated IHBECs fragments. The dispersed cells were counted on the hemocytometer with trypan blue and allowed to settle, then resuspended in GM, and plated onto collagen-coated, $35 \mathrm{~mm}$ plastic dishes (BD) or 12-well dishes (BD) and maintained at $37^{\circ} \mathrm{C}$ in a humidified $5 \% \mathrm{CO}_{2}$ incubator. After 3 days in GM, the media was changed to serum- and insulin-free differentiation medium (DM), which consisted of DMEM/F12 (Gibco) supplemented with $10 \mathrm{mM}$ nicotinamide (Sigma), $1 \mathrm{mM}$ ascorbic acid 2-phosphate (Sigma), $10 \mathrm{mM}$ MEM Vitamin Solution (Gibco), $10 \mathrm{mM}$ MEM non-essential amino acids solution, $10 \mathrm{mM}$ GlutaMA-I Supplement (Gibco), $4 \mathrm{mg} / \mathrm{ml}$ transferrin (Invirogen), $10 \mathrm{ng} / \mathrm{ml}$ 
betacellulin (R\&D), $10 \mathrm{ng} / \mathrm{ml}$ IGF-I (R\&D), and $50 \mathrm{ng} / \mathrm{ml}$ exendin-4 (Sigma). The IHBECs were cultured for an additional 2 days and randomly divided into three groups; the cells were maintained in this condition (Group 1), transduced with Ad expressing - green fluorescent protein (GFP; Group 2), or transduced with Ad expressing - $P d x-1$, -Neurogenin 3 (NEUROG3), -NeuroD, -Pax 4, and -Pdx1/VP16 (Group 3). The media were changed every 2 days.

\section{Preparation of recombinant adenoviruses}

Recombinant Ad expressing $P d x-1$, -Neurog3, -NeuroD, and $-P d x-1 / V P 16$ driven by a cytomegalovirus (CMV) promoter were prepared with the AdEasy system as previously described (Kaneto et al. 2005). These AdVs all carried the reporter GFP. The control Ad (Ad-GFP) was prepared in the same manner. Ad expressing Pax4 (Ad-Pax4) was kindly provided by Dr St-Onge (DeveloGen AG, Gottingen, Germany) and contains the construct of CMV-Pax4-IRES-GFP.

The integration of each gene into the Ad was done by transfection into the Ad packing cell line 293 cells according to the manufacture's instructions. Ad titers were further increased up to $1 \times 10^{10}$ plaque forming units $/ \mathrm{ml}$ with Vivapure AdenoPACK 100 purification kits (Vivascience, Edgewood, NY, USA).

\section{Transduction of adenovirus to IHBECs}

For transduction, media were changed to serum-free DMEM containing purified recombinant Ad -PDX-1, -NGN 3, -NEURO D, -PAX4 or -PDX-1/VP16 and incubated for $1 \mathrm{~h}$ at $37^{\circ} \mathrm{C}$. To test which multiplicity of infection (MOI) was most effective for transduction, IHBECs were infected at MOIs of $1,10,25,50,100$ or 200 for $2 \mathrm{~h}$ at $37^{\circ} \mathrm{C}$. Two-days after transduction, cells were counted to determine the percentage of $\mathrm{GFP}^{+}$cells. Seven days after transduction, the cells were harvested and evaluated.

\section{RNA isolation, cDNA synthesis, RT-PCR}

Total RNA was isolated from cultured cells at day 26 using RNeasy Mini Kits (Qiagen) according to manufacturersuggested protocols, and RT-PCR were conducted. The extracted total RNA was reverse-transcribed into cDNA with Omniscript RT Kit (Qiagen) using standard procedures. The primers were complementary to the mRNA sequences of the genes of interest and are listed in Supplementary Table 1, see Supplementary data in the online version of the Journal of Endocrinology at http://joe.endocrinology-journals.org/ content/vol201/issue1/. All the primers were designed to cross exon-exon boundaries to exclude the possibility that genomic DNA was amplified. The exception was MafA that lacks an intron. Twenty nanograms cDNA were applied to each well. PCR was performed with the following parameters: 36 cycles of $30 \mathrm{~s}$ at $94{ }^{\circ} \mathrm{C}, 90 \mathrm{~s}$ at $60^{\circ} \mathrm{C}, 90 \mathrm{~s}$ at $72{ }^{\circ} \mathrm{C}$.

\section{Cell sorting}

All samples were analyzed on an ARIA cell sorter with the Summit software (BD). The cells were dispersed to mostly single cells. Propidium iodide (PI, Sigma) was used for exclusion of dead cells; we gated both $\mathrm{PI}^{-} \mathrm{GFP}^{+} / \mathrm{PI}^{-}$ $\mathrm{GFP}^{-}$populations to retrieve living cells from $\mathrm{PDX}-1 / \mathrm{VP} 16$ transduced cells. Both GFP + and GFP - single cells were placed into 96- well dishes. Group 1 and Group 2 cells were also dispersed into single cells and served as controls.

\section{Analysis of single cells by RT-PCR}

To detect our genes of interest from single cells, nested PCR was performed. Multiplex single-cell RT-PCR analysis was performed according to a previously described method with some modifications (Miyamoto et al. 2002). Briefly, we first performed reverse-transcription followed by the first PCR. Sorted single cells were deposited into 96-well U-bottom plates (BD) with $7 \cdot 5 \mu$ lysis and RT buffer containing gene-specific reverse primers for Krt19, NeuroD, Pdx-1, Ins 1, Ins 2, Glucagon, Somatostatin, PP, and HPRT (Supplementary Table 1): the concentration of lysis buffer was the following: $(1 \times$ First, Strand Buffer (Invitrogen), $10 \mathrm{mM}$ dithiothreitol (Invitrogen), $1 \mathrm{mM}$ dNTPs (New England BioLabs, Ipswich, MA, USA), 0.5\% Triton X-100 (Sigma), $0 \cdot 1 \% \mathrm{BSA}, 10 \mathrm{U} / \mu \mathrm{l} \mathrm{M}-\mathrm{MLV}$ reverse transcriptase

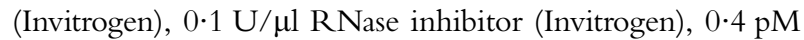
reverse primers). Retrieved cells were lysed by pipetting several times in the plate, and then cell lysates were transferred to 96-well optical Reaction Plate with Barcode (Applied Biosystem, Foster City, CA, USA). After incubation at $37^{\circ} \mathrm{C}$ for $90 \mathrm{~min}$, the samples were incubated at $94^{\circ} \mathrm{C}$ for $30 \mathrm{~s}$ to inactivate the enzyme. This step is reverse-transcription and cDNAs are generated simultaneously. The first-round of PCR was carried out in the same plate by addition of premixed PCR buffer containing the gene-specific forward primers $(1 X$ GeneAmp PCR Gold Buffer (Applied Biosystem), $2 \cdot 5 \mathrm{mM}$ $\mathrm{MgCl}_{2}$, AmpliTaq Gold $0 \cdot 1 \mathrm{U} / \mu \mathrm{l}, 0 \cdot 1 \mathrm{pM}$ forward primers). The total volume of the first PCR reactions were $20 \mu$, and PCR was performed with the following parameters: 36 cycles of $30 \mathrm{~s}$ at $94^{\circ} \mathrm{C}, 90 \mathrm{~s}$ at $60^{\circ} \mathrm{C}, 90 \mathrm{~s}$ at $72^{\circ} \mathrm{C}$. For nested PCR, the second round PCR was performed as follows: $1 \mu \mathrm{l}$ of the first-round PCR reactions were plated into new PCR plates, which contained mixed buffer $(1 \times$ GeneAmp PCR Gold Buffer (Applied Biosystem), $2.5 \mathrm{mM} \mathrm{MgCl}_{2}$, AmpliTaq Gold (Applied Biosystem) 0.1 U/ $\mu$, and $0 \cdot 25 \mathrm{pM}$ forward primers). For the second-round PCR, each gene was analyzed separately using nested gene-specific primers with the following parameters: 35 cycles of $36 \mathrm{~s}$ at $94^{\circ} \mathrm{C}, 90 \mathrm{~s}$ at $60^{\circ} \mathrm{C}, 90 \mathrm{~s}$ at $72{ }^{\circ} \mathrm{C}$. Aliquots of second-round PCR products were subjected to gel electrophoresis. Two hundred pg of total RNA isolated from mouse islets was used as a positive control. 


\section{Immunostaining}

The methods used for immunostaining have been previously described (Nagaya et al. 2006). Briefly, cells on dishes were fixed in cold absolute ethanol after three rinses with PBS. Primary antibodies included mouse anti-cytokeratin 7 (1:25; CK7; Dako Cytomation), rabbit anti-cytokeratin 19 (1:1000; KRT19; a gift of Dr A Miyajima, Tokyo University, Japan), rabbit anti-NeuroD (1:200; Cell Signaling Technology, Inc., Danvers, MA, USA), rabbit anti-Pdx-1 (1:2000; IPF-1C antibody, a gift from Dr J M W Slack, University of Minnesota) and rabbit anti-C-peptide (1:400; Cell Signaling). Alexa ${ }^{488}$-conjugated and Alexa ${ }^{594}$-conjugated antibodies (Molecular Probes, Eugene, OR, USA) were used as secondary antibodies. Cell nuclei were counter-stained with PI (VECTASHIELD Mounting Medium with PI; Vector Laboratories, Ltd., Peterborough, England) or DAPI (VECTASHIELD Mounting Medium with DAPI). Cultures processed with secondary antibodies only were used as negative controls. Liver and pancreas sections were stained as positive controls.

\section{Measurement of insulin production}

Insulin levels in culture supernatants were measured using the ultrasensitive insulin ELISA (Crystal Chem, Inc, Downers Grove, IL, USA; detection limit of $0.04 \mathrm{ng} / \mathrm{ml}$ ). Media from cultures from day 5 to day 7 after transduction were collected and measured as basal secretion. Subsequently, insulin secretion in response to secretagogues was measured, the cells were subjected to static incubation in Krebs-Ringer bicarbonate buffer (KRB; $133 \mathrm{mM} \mathrm{NaCl}, 4.69 \mathrm{mM} \mathrm{KCl}$, $1 \cdot 2 \mathrm{mM} \mathrm{KH} \mathrm{KO}_{4}, 1 \cdot 2 \mathrm{mM} \mathrm{MgSO} 4,25 \mathrm{mM}$ HEPES, $2.52 \mathrm{mM} \mathrm{CaCl}, 2 \mathrm{H}_{2} \mathrm{O}, 5 \mathrm{mM} \mathrm{NaHCO}_{3}$ ) supplemented with $5 \mathrm{mM}$ glucose and $0 \cdot 2 \%$ BSA. Plated in 12-well culture plates (BD), cells were washed four times with KRB. They were continuously incubated in KRB with low glucose $(5 \mathrm{mM})$, high glucose $(25 \mathrm{mM})$ or high glucose with $45 \mathrm{mM}$ $\mathrm{KCl}$ for $2 \mathrm{~h}$ at $37^{\circ} \mathrm{C}$. Between each incubation, they were washed four times with KRB and incubated in KRB for $2 \mathrm{~h}$. IHBECs (Group 1, $n=3$ ), control cells (Group 2, $n=3$ ), transduced cells (Group 3, the number of independent experiments with $\mathrm{Pdx}-1$ was $n=6$; NeuroD, $n=7$; and $\mathrm{Pdx}-1 / \mathrm{VP} 16, n=7)$. Fold stimulation was calculated for each culture $\left(1 \times 10^{5}\right.$ cells/well per $\left.\mathrm{ml}\right)$ by dividing the insulin concentration in the stimulation supernatant by the insulin concentration in the basal supernatant.

\section{Statistical analysis}

Experimental results were expressed as the mean \pm s.E.M. Student's t-test, ANOVA and Fisher's protected least significant difference test were used, and $P<0.05$ was considered significant. All experiments were repeated at least three times.

\section{Results}

\section{Generation of insulin-producing cells from IHBECs}

We have developed a five step-protocol for inducing the differentiation of IHBECs to insulin producing cells (Fig. 1). In Step 1, the IHBEC-rich fraction was isolated from adult mouse liver with $1 \times 10^{5}$ viable cells/mouse being recovered, then in Step 2 their number was expanded with CEFCM. Figure 2A left and B left show macroscopic and phase contrast microscopic views respectively. After about 5 days with CEFCM, IHBECs formed three-dimensional ductal cysts (Fig. 2B, right) and rapidly expanded their number about

Step 1. Isolation of IHBEC-rich fraction from mouse (day 0).

Step 2. Isolated cells expanded with collagen-embedded floating culture method (CEFCM) (days 0-14).

Step 3. Seed IHBECs onto collagen culture dishes to make monolayers for 3 days in growth medium. (days 14-17)

Step 4. Media changed to serum-and insulin-free differentiation medium (DM); IHBECs cultured for an additional 2 days (days 17-19). Cells divided into three groups. Group 1 continued to be exposed to this condition.

Step 5. Differentiation manipulations. IHBECs transduced with adenoviral-mediated pancreatic transcription factors including Pdx-1, Neuro D-, Pdx-1/VP 16-GFP (Group 3) or GFP (Group 2) (days 19-26).

Step 6. Evaluation of the IHBECs phenotype.

\begin{tabular}{|c|c|c|c|c|}
\hline Group 1 & Step 2 & Step 3 & & Step 4 \\
\hline Group 2 & Step 2 & Step 3 & Step 4 & Step 5 (control vector) \\
\hline Group 3 & Step 2 & Step 3 & Step 4 & Step 5 \\
\hline
\end{tabular}

Figure 1 General outline of the culture system and protocols for inducing the differentiation of IHBECs. 
15-fold within 2 weeks (Fig. 2E). The CG containing the expanding cells gradually shrank over 14 days (Fig. 2D). In cultures without CEFCM (CEFCM-), IHBECs initially expanded but then started to die at around 8 days (Fig. 2E).

Initial experiments with IHBECs were performed to determine their behavior in tissue culture and their potential for transdifferentiation. RT-PCR and immunofluorescent staining were carried out with hepatocyte, biliary epithelial cell (BEC), and islet markers. Cells at day 0 expressed BEC markers but neither hepatocyte nor islet markers (Fig. 2F). In addition, IHBECs expressed a number of hepatocyte nuclear factor (HNF) family genes, (HNF1 $\beta, H N F 3 \beta$, $H N F 4 \alpha, H N F 6$ ) considered to be endoderm progenitor markers (Lemaigre \& Zaret 2004). The cells were also positive for both CK7 (blue; Fig. 2G) and KRT19 (data not shown).

At day 14, dispersed IHBECs were seeded onto collagencoated dishes and cultured for 3 more days (Step 3). These
IHBECs formed colonies and expanded about 2.4-fold during these 3 days. At day 17, cultured IHBECs without CEFCM displayed signs of senescence (large, multinucleated flat cells; Fig. 3A, black arrows) or numerous cytoplasmic vacuoles (Fig. 3A, white arrow heads). IHBECs subjected to CEFCM culture had fewer senescent cells or cytoplasmic vacuoles (Fig. 3B). These monolayers of homogenous appearing cells maintained their BEC character even at day 17 (Fig. 2F) and proliferated efficiently in culture (Fig. 2G, right). The purity of IHBECS averaged $>90 \%$ at day 17 as assessed by immunostaining for CK7 and KRT19.

For Step 4, the media was changed to DM and the IHBECs were cultured for an additional 2 days. We focused first on generating insulin-expressing cells by testing soluble factors including activins, exendin-4, HGF, IGFs, nicotinamide, and betacellulin. After seven additional days (Step 5) in DM Control (Group 1), IHBECs started to express
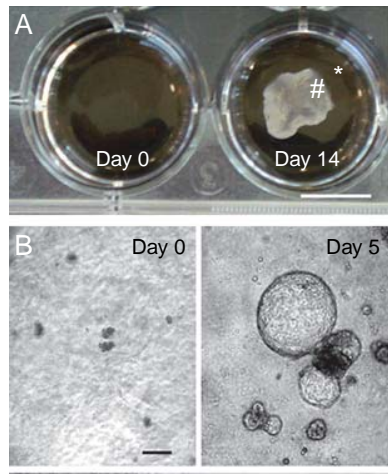

D Diameter of collagen gel

E Number of IHBECs
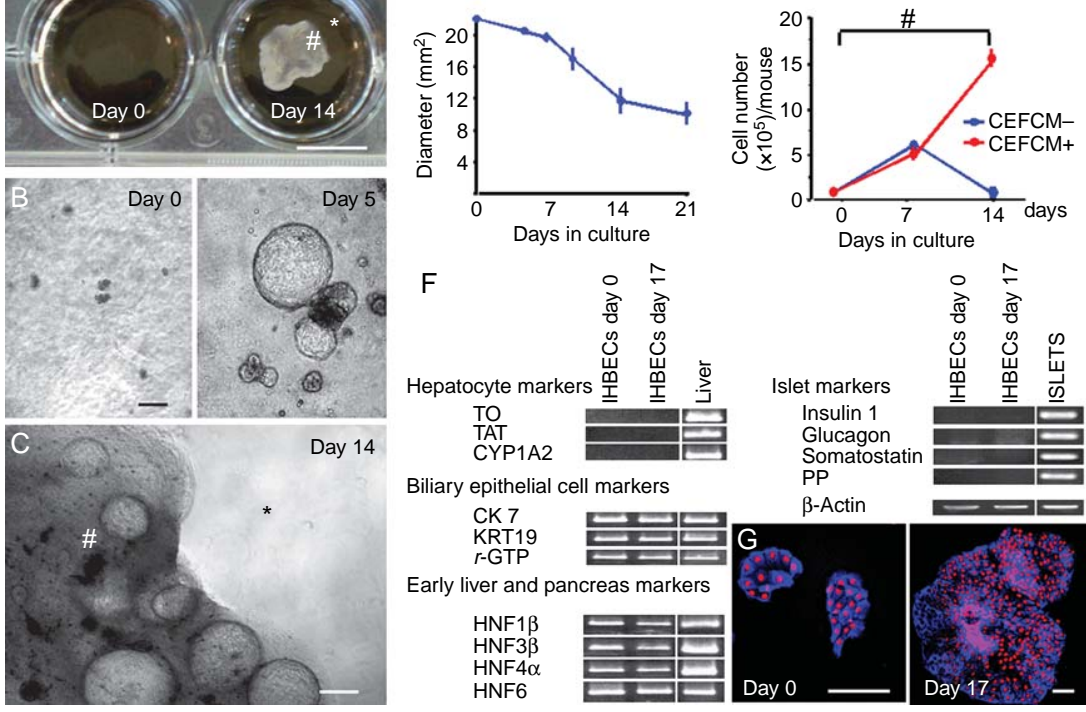

Biliary epithelial cell markers

CK 7

KRT19

Early liver and pancr

HNF1 $\beta$
HNF3 $\beta$
HNF4 $\alpha$

HNF $4 \alpha$
HNF6

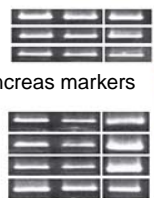

Figure 2 (A-G) IHBECs cultured with collagen embedded floating culture method (CEFCM). (A) Macroscopic appearance of IHBECs with CEFCM. Isolated IHBECs were suspended in rat tail collagen plus GM; the collagen gel containing the IHBECs gradually contracted. Scale bar, $10 \mathrm{~mm}$. (B) Nomarski differential interference contrast (DIC) image of cultured IHBECs. Day 0 with CEFCM (B, left); Very small aggregates of IHBECs. After 5 days with CEFCM, IHBECs formed three-dimensional ductal cysts (B, right). (C) IHBECs at 14 day with CEFCM. Asterisk shows the same position as in panel A. IHBECs rapidly expanded to form ductal structures. Scale bar, $100 \mu \mathrm{m}$. (D) The diameter of collagen gel gradually shrank with time. (E) The number of IHBECs in each group. Bars show mean \pm s.E.M. of 5 independent experiments. $\# P<0 \cdot 001$. (F) Gene expression profiles of IHBECs and immunofluorescence staining for cytokeratin 7. RT-PCR was carried out to clarify the character of IHBECs at day 0 and day 17 . Hepatocyte markers (tryptophan oxygenase $(T O)$, tyrosine aminotransferase (TAT), cytochrome P450 1A2 (CYP1A2)), BEC markers (Cytokeratin (CK)7 and 19, $\gamma$-glutamyltranspeptidase $(\gamma$-GTP), islet markers (Insulin 1, Glucagon, Somatostatin, and Pancreatic polypeptide $(P P)$ ), and what are considered to be endoderm progenitor markers (HNFs1 $\beta, 3 \beta, 4 \alpha$, and 6). The oligonucleotide primers and cycle number used for semiquantitative PCR are shown in Supplementary Table 1. Mouse liver and islets were used as controls. Gene expression studies in all groups were repeated at least three times independently. (G) Immunofluorescent analysis for CK7 in IHBECs. IHBECs were positive for both for CK7 (blue) at days 0 (G, left) and 17 (G, right). Propidium iodide (PI, red) was used to show nuclei. Scale bar, $100 \mu \mathrm{m}$. 

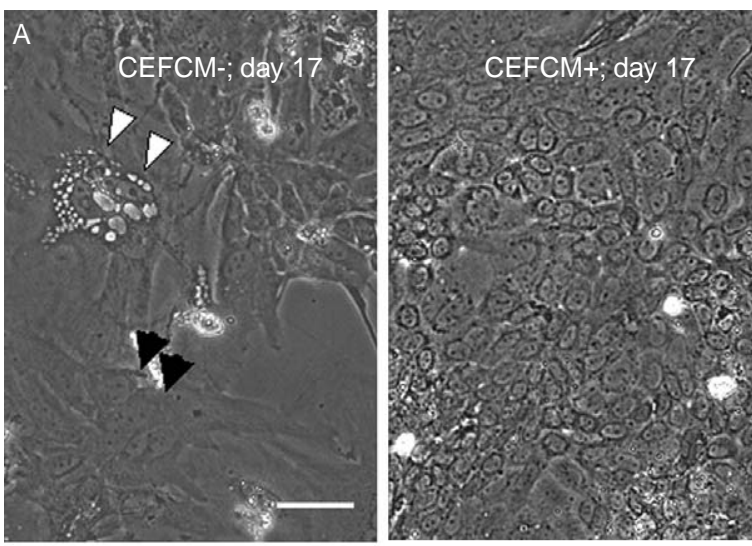

$100 \mu \mathrm{m}$

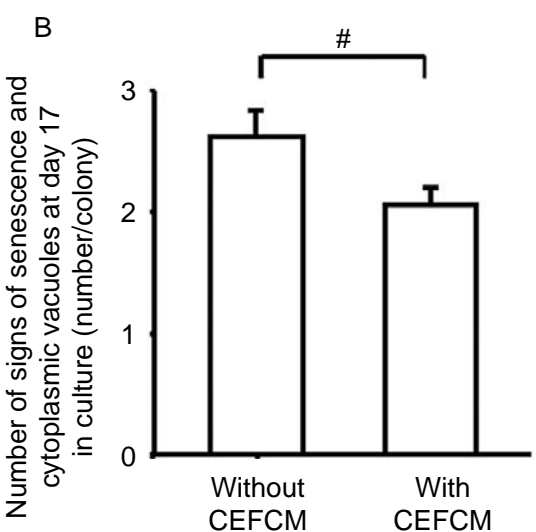

Figure 3 (A) Nomarski differential interference contrast (DIC) image of IHBECs at day 17. Left panel: when the cells were cultured for 17 days without CEFCM, they displayed signs of senescence. Black arrowheads show large, multinucleated flat cells; white arrowheads show numerous cytoplasmic vacuoles. Right panel: cells were cultured with CEFCM (CEFCM+). The cells were cultured with CEFCM for 14 days, then dispersed and seeded onto collagencoated dishes and cultured for 3 days (total 17 days), and then form a monolayer of homogenous appearing cells. Scale bar, $100 \mu \mathrm{m}$. (B) Quantification of senescent cells at day 17 as judged by the presence of senescence and cytoplasmic vacuoles. The number of aggregates that contain signs of senescence or cytoplasmic vacuoles were counted and compared between CEFCM- and CEFCM+ cultures at day 17 . At least three colonies per well that were at least $1 \mathrm{~mm}$ apart were selected in each of five independent experiments. A total of fifty colonies were checked in each of the group. Data are depicted as mean \pm S.E.M. of five independent experiments. $\# P=0 \cdot 016$.

some endocrine progenitor genes (Ngn 3, NeuroD, Nkx6.1 and $P d x-1$ ), but lacked Ins mRNA (Fig. 5A). Therefore, we decided to transduce the IHBECs with $A d-P d x-1$, -Neurog3, -Neuro D, -Pax4 and -Pdx-1/VP16.

\section{Transduced IHBECs with Ad-Pdx-1, NeuroD,} or $P d x-1 / V P 16$

MOI of 50 MOI for Pdx-1, Neurog3, NeuroD, Pax 4 or 100 for $\mathrm{Pdx}-1 / \mathrm{VP} 16$ with recombinant Ad resulted in efficient expression of the transgenes with 30-50\% transduction efficiency and high cell survival (Supplementary Figure 1, see Supplementary data in the online version of the Journal of Endocrinology at http://joe.endocrinology-journals.org/ content/vol201/issue1/). We found that MOIs of 100-200 resulted in toxicity and loss of cells.

\section{Gene expression profiles of IHBECs-derived} insulin-producing cells

To analyze the molecular events occurring in IHBECs during the series of culture steps, gene expression profiles of transcription factors and pancreas-related genes were determined by RT-PCR. IHBECs at Step 1 only expressed BEC markers and early liver and pancreas markers (Fig. 2F). At the end of Step 4, Group 1 cells expressed the pancreatic progenitor markers Neurog3, NeuroD, Nkx6.1, Pdx-1, and pancreas-specific transcription factor $1 \alpha$ (Ptf1 $\alpha$; Fig. 4A). These genes were not observed in cultured IHBECs at day14, therefore, the IHBECs assumed these characteristics in DM culture. Transduced expression of $P d x-1$, NeuroD or $P d x-1 /$ $V P 16$ led to expression of not only both Ins 1 and 2 but also Glut2 and prohormone convertases 1 and 2 (PC1 and 2). Glucokinase was also expressed at this stage (data not shown). $P d x-1$ or $P d x-1 / V P 16$ transduced cells faintly expressed amylase (Fig. 4A). Expression of Ptf1 $\alpha$ was found in all groups. Neither Ad-NEUROG3 nor Ad -PAX4 led to express Ins, therefore, their use were discontinued.

\section{Immunostaining of IHBECs 7 days after transduction} with $A d-P d x-1 / V P 16$

PDX-1/VP16 transduction led to the appearance of endocrine precursor and islet related markers. Using immunofluorescence analysis, cells stained for NEUROD ${ }^{+}$ (nuclear) co-expressed both GFP and CK7 (cytoplasm; Fig. 5A). There was complete overlap of NEUROD and DAPI in the nuclei (Fig. 5B). A relatively small number of $\mathrm{NEUROD}^{+} \mathrm{GFP}^{-}$cells were seen (data not shown). Cells with nuclear $P d x-1$ staining also co-expressed GFP and CK7 (Fig. 5C). As expected, due to the $P d x 1 / V P 16$ transduction the number of $P d x-1^{+}$cells was larger than that of $\mathrm{NEUROD}^{+}$cells (Fig. 5C). C-peptide staining confirmed the synthesis of insulin by IHBECs-derived insulin-producing cells. We found that $30 \cdot 1$ and $2 \cdot 8 \%$ of 4000 cells counted in $P d x-1 / V P 16$ transduced cultures were $\mathrm{GFP}^{+}$and C-peptide ${ }^{+}$respectively (Fig. 5E and F). Of the GFP+ cells, about $6 \%$ were strongly stained for C-peptide.

Insulin release into the culture medium by clusters of IHBECs-derived insulin-producing cells

Insulin release into the culture medium was measured at 7 days after transduction (Fig. 5G). From day 5 to day 7 after transduction, Ad- $P d x-1$, NeuroD, and $P d x-1 / V P 16$ transduced IHBECs released insulin (Ad-Pdx-1 0.08 $\pm 0 \cdot 05$, 


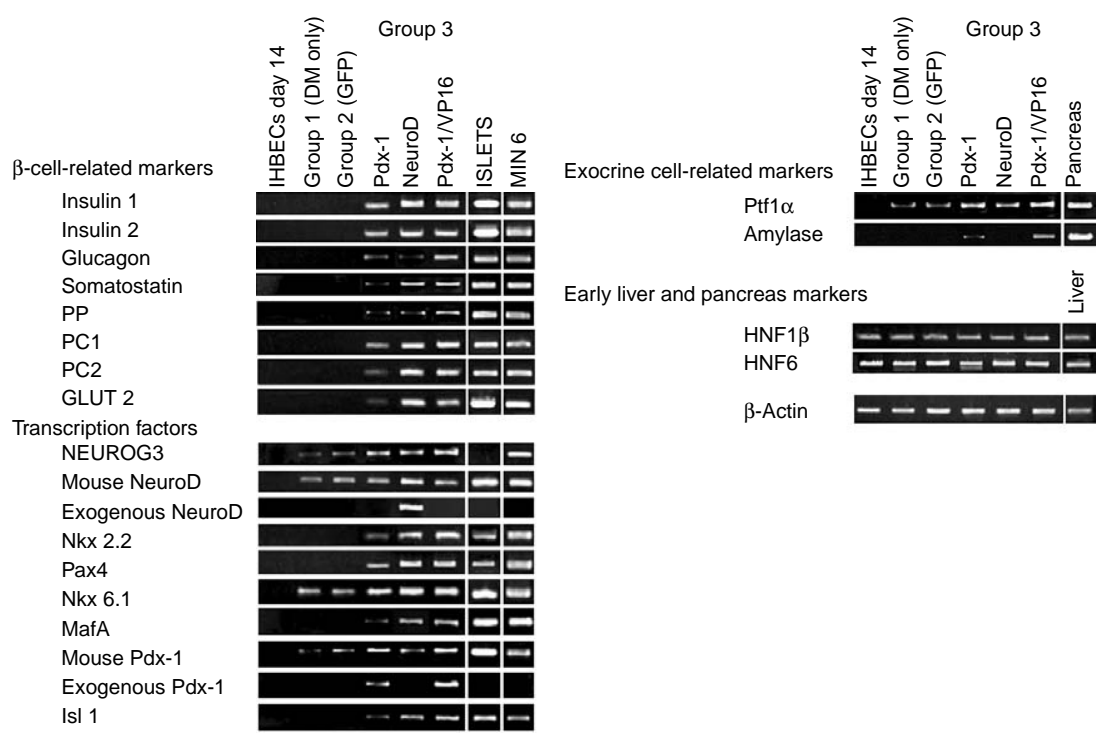

Figure 4 Gene expression profiles in each group. $\beta$-cell related markers (Insulin 1 and 2, glucagon, somatostatin, and pancreatic polypeptide, prohormone convertase (PC 1 and 2), Glucose transporter 2 (GLUT2)), transcription factors (Neurogenin3 (NEUROG3), NeuroD, Nkx2.2, Paired box4 (Pax4), Nkx6.1, MafA, Pdx-1, and Islet-1 (Is/1)), exocrine cell related markers (pancreas-specific transcription factor $1 \alpha$ (Ptf1 $\alpha)$, Amylase) and $\beta$-actin mRNA transcripts were assessed. IHBECs at day 14 in culture were used as a control. Mouse islets, insulinoma cell line MIN6, pancreas were controls. Findings are representative of at least three independent experiments for each. The oligonucleotide primers and cycle number used for semiquantitative PCR are shown in Supplementary Table 1.

Ad-NeuroD $0 \cdot 33 \pm 0 \cdot 09$, Ad-Pdx-1/VP16 $0 \cdot 37 \pm 0 \cdot 14 \mathrm{ng} /$ $1 \times 10^{5}$ cells after $48 \mathrm{~h}$ in culture). As controls, the cells from Groups 1 and 2 did not have detectable insulin release (Fig. 5G).

We also monitored the release of insulin into the culture medium in response to various stimuli supplied sequentially over $2 \mathrm{~h}$ intervals for group 3 cells. No basal insulin release could be detected for any of the transduced cells, but after exposure to $25 \mathrm{mM}$ glucose or $45 \mathrm{mM} \mathrm{KCl}$, barely measurable amounts of insulin from $P d x-1 / V P 16$ transduced cells were found in a small number for experiments. Little can be concluded from these inconsistent results. Questions could be raised about, whether $25 \mathrm{mM}$ glucose is high enough to have a glucose toxicity effect. Because such a concentration has been used successfully so often in other studies, we doubt this type of toxicity is contributing much to the low secretion.

\section{Characterization of transduced IHBECs with single cell PCR}

From the previous results, it was clear that some IHBECs transduced with PDX-1, NEURO D, PDX-1/VP16 produced insulin. We therefore attempted to characterize these cells on a single cell level. GFP + and GFP - single cells from PDX-1/VP16 transductions were placed into wells of 96-well dishes by the ARIA sorter. We gated both $\mathrm{PI}^{-} \mathrm{GFP}^{+}$ populations to retrieve only living cells (Fig. 6B). Group 1 cells were also dispersed into single cells and used as controls
(Fig. 6A). Both $\mathrm{PI}^{-} \mathrm{GFP}^{+}$populations from Group 2 were also analyzed by the same manner. Twenty three percent of $\mathrm{GFP}^{+}$cells expressed both the insulin 1 and 2 genes in Ad-PDX-1/VP16 transduced IHBECs; cells always expressed both or neither insulin genes. These Ins 1 and 2 expressing cells also expressed endogenous Neuro $D$ and $P d x-1$ genes (data not shown). Importantly, these cells expressed other marker genes including islet genes (Glucagon, Somatostatin, and $P p y$ ) and KRT19 (Table 1C). Neither cells in control group 1 nor GFP negative cells in PDX-1/VP16 transduced cells exhibited insulin gene expression (Table 1A and B). Cells in group 2 were similar to the result of group 1 . Twenty eight percent of cells from group 2 expressed $P d x-1$, however, they lacked Ins gene expression.

\section{Discussion}

We characterized the differentiation process of transduced IHBECs at the RNA level using RT-PCR, and at protein levels with immunofluorescence and ELISA. To convincingly show that IHBECs produced insulin, exogenous insulin was eliminated from step 4 because apoptotic cells can take up exogenous insulin from the culture medium (Rajagopal et al. 2003). We found both insulin mRNA as well as de novo synthesis of C-peptide by immunocytochemistry. We have not yet determined the relative proportions of proinsulin to 
insulin, but expect that full processing has not taken place in these cells that are not fully differentiated. Our findings demonstrated that IHBECs can be transdifferentiated to insulin-producing cells.

The transcription factors HNF1 $\beta$, HNF3 $\beta, \mathrm{HNF} 4 \alpha$, HNF6 are islet progenitor markers (Wilson et al. 2003), which form a transcriptional network that coordinates $\beta$-cell development and function (Rausa et al. 1997, Sumazaki et al. 2004, Zaret 2008). Even though HNF1 $\beta$ in such cells is
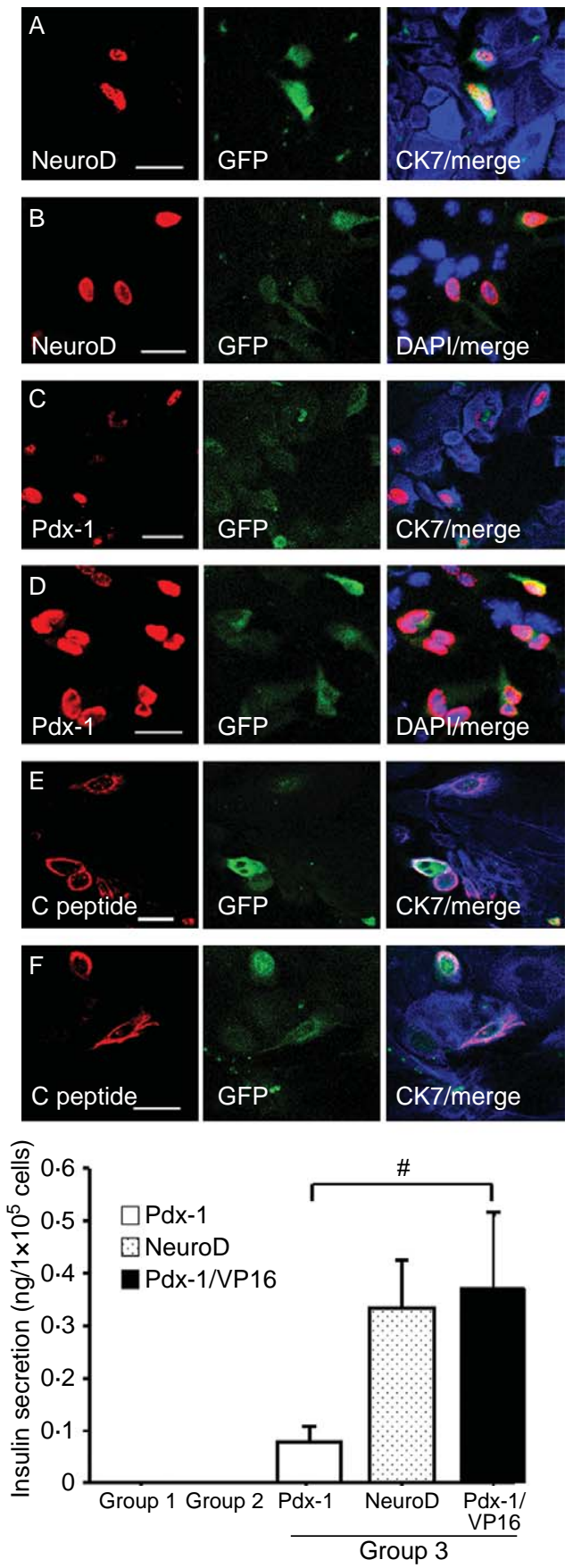

Journal of Endocrinology (2009) 201, 37-47 downstream of HNF6, it has a crucial role for BECs development (Clotman et al. 2002, Lemaigre \& Zaret 2004). Moreover, the expression of HNF1 $\beta$ to define a cellular population that forms the primitive pancreatic ducts (Rausa et al. 1997). Such embryonic duct HNF1 $\beta^{+}$cells are phenotypically distinct from earlier pancreatic bud cells, and evidence suggests that they are direct precursors of the $\mathrm{NEUROG}^{+}$endocrine progenitor cells required for endocrine cell formation (Jacquemin et al. 2000, Xu et al. 2008). We found that IHBECs even at an early stage possessed these important initiation transcripts (Fig. 2) and that Neurog3 gene was induced in IHBECs at step 4 even without molecular engineering.

Even though IHBECs are attractive targets for transdifferentiation, the previous techniques for isolation of IHBECs have been cumbersome and associated with a low yield of cells (Alvaro et al. 1993, Alpini et al. 1997, 2003). Furthermore, in vitro studies with freshly isolated cells or intrahepatic bile duct units fragments are limited by the lack of long-term ( $>24 \mathrm{~h}$ ) viability (Alpini et al. 2003). Therefore, expansion to obtain significant quantities of healthy IHBECs was an important goal. We thought that maintenance of the polarized characteristics of biliary epithelium might facilitate that goal and postulated that a three-dimensional matrix might be helpful. It has been found that three-dimensional culture conditions can allow polarized cells to keep their original character (Grünert et al. 2003, Matsuoka et al. 2006). As indicated in Fig. 2E, many cells died within 2 weeks when cultured in two-dimensional conditions. Because the media with its growth factors and collagen were the same with two dimensions versus three-dimensional cultures, we assume there is some effect of the three-dimensional geometry that promoted expansion and improved viability.

From step 4, our serum- and insulin-free DM was used in hopes of priming the cells for transdifferentiation. Indeed, these cells began to express the pancreatic progenitor markers

Figure 5 Immunofluorescence analysis and Insulin release into the culture medium at 7 days after transduction. (A-F) Immunofluorescence analysis of Ad- Pdx-1/NP16 transduced IHBECs at 7 days after transduction. (A-D) Immunofluorescence analysis of transitions from endocrine precursor to hormone-expressing cells.

(A) Triple staining for NeuroD (red), GFP (green), and CK7 (blue). (C) Triple staining for Pdx-1 (red), GFP (green), and CK7 (blue).

(B, D) Nuclear staining for NeuroD and Pdx-1. Fluorescence micrographs showing expression of NeuroD (B) or Pdx-1 (D). DAPI shown in blue. There was a complete overlap between transcription factors and DAPI in the nuclei. (E, F) C-peptide staining for Ad- Pdx1/VP16 transduced IHBECs 7 days after transduction. Triple staining was for C-peptide (red), GFP (green), and CK7 (blue). Of 4000 cells counted, $2 \cdot 8 \%$ in Pdx-1/NP16 transduced cultures stained strongly for C-peptide. 4000 counted cells from five independent experiments. Scale bars, $50 \mu \mathrm{m}$. (G) Insulin release into the culture medium after $48 \mathrm{~h}$ incubation of Ad- Pdx-1/VP16 transduced IHBECs at 7 days after transduction. The insulin levels in IHBECs (Group 1), control cells (Group 2), transduced cells (Group 3, Ad-Pdx-1: white column, Ad-NeuroD: dotted column, Ad-Pdx1/VP16: black column) were assessed. $\# P=0 \cdot 0495$. Data are means \pm S.E.M. of 3-7 independent experiments. 

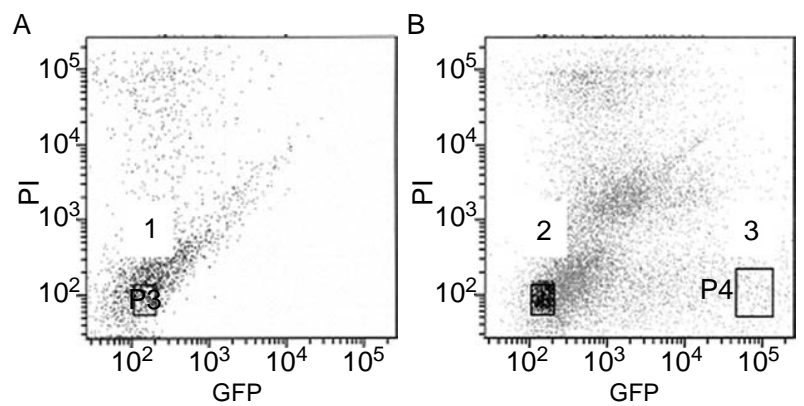

Figure 6 (A, B) Flow cytometry analysis of Ad- PDX-1/VP16 transduced IHBECs 7 days after transduction. (A) Flow cytometry analysis of group 1. (1) The cells from IHBECs in DM (non-transduced). (B) Flow cytometry analysis of Ad-PDX-1/NP16 transduced IHBECs 7 days after transduction. (2) Ad-PDX-1/NP16 transduced IHBECs, but non-emitter cells. (3) Ad-PDX-1/VP16 transduced IHBECs. DM, differentiation medium.

NEUROD, NEUROG3, NKX6.1, PDX-1, and PTF1 $\alpha$ (Fig. 4A). If the cells were exposed to GM at this stage, they proliferated and did not express these transcripts (data not shown). Work by Gershengorn et al. (2004) showed that to induce insulin mRNA in cytokeratin positive cells, elimination of EGF and the use serum free medium was important.

During stage 4 in DM culture, markers for both pancreatic epithelial progenitors and endocrine precursors were found. Recent reports find that Ptf $1 \alpha$ is expressed in the progenitors of pancreatic ducts, exocrine, and endocrine cells, rather than being an exocrine-specific gene as previously thought (Kawaguchi et al. 2002). Thus, co-expression of PTF1 $\alpha$ and PDX-1 is required for proper pancreatic determination and subsequent differentiation (Kawaguchi et al. 2002, Afelik et al. 2006, Wiebe et al. 2007). IHBECs cultured for 14 days did not express PTF1 $\alpha$; however, all groups of cells expressed PTF1 $\alpha$ after DM culture. It is possible that expression of PTF1 $\alpha$ is a prerequisite for transdifferentiation. The combined use of a two-dimensional culture environment and DM accerelated differentiation pathways toward pancreatic fate but failed to induce insulin gene expression (Fig. 4A). Seven days after transduction with Ad-PDX-1, NEUROD, or PDX-1/VP16, insulin expression was found by RT-PCR, immunofluorescence and ELISA. To further characterize these cells, we examined islet hormone gene expression in single cells that had been transduced with PDX-1/VP16 and found that $91 \%$ of Ins 1 and 2 positive single cells expressed all four islet hormone genes (Table 1). This expression of multiple islet hormones likely reflects immaturity as previous studies have found that islet cells can express more than one of these islet hormones simultaneously (Alpert et al. 1988, De Krijger et al. 1992, Teitelman et al. 1993). It is clear that some of these transduced cells have insulin gene expression and contain insulin protein. We can be confident that this insulin resulted from biosynthesis rather than uptake from the medium, as judged by the following criteria: 1) no insulin was detected in GFP transduced IHBECs in the same conditions, 2) insulin was detected in transduced IHBECs in DM that was not

Table 1 Single cell analysis with nested PCR; heterogeneity of islet hormone gene expression in adenoviral (Ad)- pancreas duodenum homeobox $1(\mathrm{Pdx}-1)$ /VP16 transduced intrahepatic biliary epithelial cells (IHBECs) 7 days after transduction. Separate primers were used for Ins1 + Ins2, but all insulin expressing cells expressed both Ins1 and Ins2

HPRT CK19 Pdx-19

(A) IHBECs in DM (Group 1)

(B) GFP negative cells from Pdx-1/NP16 transduced cell population (Group 3)

+
+
+
+

Number/\% $\quad \stackrel{+}{66}(100)$

-
+
+
+

$64(97)$
Pdx-1

-
-
+
+

$18(27)$
Ins1+ Ins2

$\begin{array}{ll}- & 2(3) \\ - & 46(70) \\ - & 18(27) \\ + & 0(0)\end{array}$

$0(0)$
Number/(\%)

$8(27)$

$0(0)$

$1(2)$

39 (59)

26 (39)

$0(0)$

Number $\%$

$\begin{array}{ll}- & - \\ + & - \\ + & + \\ + & +\end{array}$
65 (98) 26 (39)

$+$ $0(0)$

\begin{tabular}{lll}
$66(100)$ & $65(98)$ \\
\hline HPRT & CK19 & Ins1+Ins 2
\end{tabular}

Glucagon

Somatostatin $P$

PP

Number/(\%)

(C) Pdx-1/NP16 GFP positive transduced cells (Group 3)

\begin{tabular}{|c|c|c|c|c|c|c|c|}
\hline & + & - & + & - & - & - & $0(0)$ \\
\hline & + & - & - & - & - & - & $6(6)$ \\
\hline & + & + & - & - & - & - & $71(71)$ \\
\hline & + & + & + & - & - & - & $2(2)$ \\
\hline & + & + & + & + & + & + & $21(21)$ \\
\hline Number/\% & $100(100)$ & $94(94)$ & $23(23)$ & $21(21)$ & $21(21)$ & $21(21)$ & \\
\hline
\end{tabular}

DM, differentiation medium. 
supplemented with insulin, 3) both Ins 1 and 2 mRNA were detected in the cells 4) C-peptide was detected in the cells by immunofluorescence. There are differences among the cells that express insulin, which likely reflects variation in differentiation. Thus, about $23 \%$ of GFP + cells Pdx-1/ VP16 transduced cells express Insulin by nested PCR. Of these GFP + cells, about $6 \%$ were strongly stained for C-peptide. We were unable to demonstrate glucose-induced secretion from transduced cells, but future in vitro and in vivo experiments will determine the capacity of these cells for further differentiation.

Data are only presented from the experimental conditions described in the methods. We have also used various doses and combinations of other agents including nicotinamide, betacellulin, activins, hepatocyte growth factor, and exendin4 , but these efforts have not provided improved results. Work on finding optimal differentiation conditions is continuing.

In summary, it has been possible to force the differentiation of IHBECs towards a $\beta$-cell phenotype, which supports the possibility that these cells have the potential to be useful for $\beta$-cell replacement therapy.

\section{Declaration of interest}

The authors declare that there is no conflict of interest that would prejudice the impartiality of this scientific work.

\section{Funding}

This study was supported by grants from the National Institutes of Health (DK-66056 to S B W), the Juvenile Diabetes Research Foundation, the Diabetes Research and Wellness Foundation, and an important group of private donors. Help was also provided by the Advanced Microscopy, Flow Cytometry, and Specialized Assay Cores of the National Institutes of Health supported Diabetes and Endocrinology Research Center (DERC, DK 36836) of the Joslin Diabetes Center.

M N was the recipient of a scholarship from St Marianna University.

\section{Author contribution statement}

M N: Conception and design, financial support, collection and assembly of data, data analysis and interpretation, manuscript writing, final approval of manuscript.; H K: Provision of study materials. S B W: Conception and design, financial support, data interpretation, manuscript writing, final approval of manuscript; G C W: Conception and design, financial support, data interpretation, manuscript writing, final approval of manuscript.

\section{References}

Afelik S, Chen Y \& Pieler T 2006 Combined ectopic expression of Pdx1 and $\mathrm{Ptf1a} / \mathrm{p} 48$ results in the stable conversion of posterior endoderm into endocrine and exocrine pancreatic tissue. Genes and Development 20 1441-1446

Ahlgren U, Jonsson J, Jonsson L, Simu K \& Edlund H 1998 Beta-cell-specific inactivation of the mouse Ipf1/Pdx1 gene results in loss of the beta-cell phenotype and maturity onset diabetes. Genes and Development $\mathbf{1 2}$ 1763-1768.
Alpert S, Hanahan D \& Teitelman G 1988 Hybrid insulin genes reveal a developmental lineage for pancreatic endocrine cells and imply a relationship with neurons. Cell $\mathbf{5 3}$ 295-308.

Alpini G, Glaser SS, Rodgers R, Phinizy JL, Robertson WE, Lasater J, Caligiuri A, Tretjak Z \& LeSage GD 1997 Functional expression of the apical $\mathrm{Na}^{+}$-dependent bile acid transporter in large but not small rat cholangiocytes. Gastroenterology 113 1734-1740.

Alpini G, Phinizy JL, Glaser S, Francis H, Benedetti A, Marucci L \& LeSage G 2003 Development and characterization of secretin-stimulated secretion of cultured rat cholangiocytes. American Journal of Physiology. Gastrointestinal and Liver Physiology 284 G1066-G1073.

Alvaro D, Cho WK, Mennone A \& Boyer JL 1993 Effect of secretion on intracellular $\mathrm{pH}$ regulation in isolated rat bile duct epithelial cells. Journal of Clinical Investigation 92 1314-1325.

Antolovic D, Koch M, Galindo L, Wolff S, Music E, Kienle P, Schemmer P, Friess H, Schmidt J, Büchler MW et al. 2007 Hepaticojejunostomy analysis of risk factors for postoperative bile leaks and surgical complications. Journal of Gastrointestinal Surgery 11 555-561.

Bonner-Weir S \& Weir GC 2005 New sources of pancreatic beta-cells. Nature Biotechnology 23 857-861.

Bonner-Weir S, Taneja M, Weir GC, Tatarkiewicz K, Song KH, Sharma A \& O'Neil JJ 2000 In vitro cultivation of human islets from expanded ductal tissue. PNAS 9 7999-8004.

Cardona K, Korbutt GS, Milas Z, Lyon J, Cano J, Jiang W, Bello-Laborn H, Hacquoil B, Strobert E, Gangappa S et al. 2006 Long-term survival of neonatal porcine islets in nonhuman primates by targeting costimulation pathways. Nature Medicine 12 304-306.

Chae JH, Stein GH \& Lee JE 2004 NeuroD: the predicted and the surprising. Molecules and Cells 18 271-288.

Clotman F, Lannoy VJ, Reber M, Cereghini S, Cassiman D, Jacquemin P, Roskams T, Rousseau GG \& Lemaigre FP 2002 The onecut transcription factor HNF6 is required for normal development of the biliary tract. Development 129 1819-1828.

Dutton JR, Chillingworth NL, Eberhard D, Brannon CR, Hornsey MA, Tosh D \& Slack JM 2007 Beta cells occur naturally in extrahepatic bile ducts of mice. Journal of Cell Science 120 239-245.

Factor VM, Radaeva SA \& Thorgeirsson SS 1994 Origin and fate of oval cells in dipin-induced hepatocarcinogenesis in the mouse. American Journal of Pathology 145 409-422.

Ferber S, Halkin A, Cohen H, Ber I, Einav Y, Goldberg I, Barshack I, Seijffers R, Kopolovic J, Kaiser N et al. 2000 Pancreatic and duodenal homeobox gene 1 induces expression of insulin genes inliver and ameliorates streptozotocin-induced hyperglycemia. Nature Medicine 6 $568-572$.

Gershengorn MC, Hardikar AA, Wei C, Geras-Raaka E, Marcus-Samuels B \& Raaka BM 2004 Epithelial-to-mesenchymal transition generates proliferative human islet precursor cells. Science 306 2261-2264.

Grünert S, Jechlinger M \& Beug H 2003 Diverse cellular and molecular mechanisms contribute to epithelial plasticity and metastasis. Nature Reviews. Molecular Cell Biology 4 657-665.

Hering BJ, Wijkstrom M, Graham ML, Hårdstedt M, Aasheim TC, Jie T, Ansite JD, Nakano M, Cheng J, Li W et al. 2006 Prolonged diabetes reversal after intraportal xenotransplantation of wild-type porcine islets in immunosuppressed nonhuman primates. Nature Medicine 12 301-303.

Jacquemin P, Durviaux SM, Jensen J, Godfraind C, Gradwohl G, Guillemot F, Madsen OD, Carmeliet P, Dewerchin M, Collen D et al. 2000 Transcription factor hepatocyte nuclear factor 6 regulates pancreatic endocrine cell differentiation and controls expression of the proendocrine gene ngn3. Molecular and Cellular Biology 20 4445-4454.

Jonsson J, Carlsson L, Edlund T \& Edlund H 1994 Insulin-promoter-factor 1 is required for pancreas development in mice. Nature 371 606-609.

Kaneto H, Nakatani Y, Miyatsuka T, Matsuoka TA, Matsuhisa M, Hori M \& Yamasaki Y 2005 PDX-1/VP16 fusion protein, together with NeuroD or Ngn3, markedly induces insulin gene transcription and ameliorates glucose tolerance. Diabetes 54 1009-1022.

Kawaguchi Y, Cooper B, Gannon M, Ray M, MacDonald RJ \& Wright CV 2002 The role of the transcriptional regulator Ptfla in converting intestinal to pancreatic progenitors. Nature Genetics 32 128-134. 
Kofman AV, Morgan G, Kirschenbaum A, Osbeck J, Hussain M, Swenson S \& Theise ND 2005 Dose- and time-dependent oval cell reaction in acetaminophen-induced murine liver injury. Hepatology 41 1252-1261.

Kojima H, Fujimiya M, Matsumura K, Younan P, Imaeda H, Maeda M \& Chan L 2003 NeuroD-betacellulin gene therapy induces islet neogenesis in the liver and reverses diabetes in mice. Nature Medicine 9 596-603.

De Krijger RR, Aanstoot HJ, Kranenburg G, Reinhard M, Visser WJ \& Bruining GJ 1992 The midgestational human fetal pancreas contains cells coexpressing islet hormones. Developmental Biology 153 368-375.

Kroon E, Martinson LA, Kadoya K, Bang AG, Kelly OG, Eliazer S, Young H, Richardson M, Smart NG, Cunningham J et al. 2008 Pancreatic endoderm derived from human embryonic stem cells generatesglucose-responsive insulin-secreting cells in vivo. Nature Biotechnology 26 443-452.

Lemaigre F \& Zaret KS 2004 Liver development update: new embryo models, cell lineage control, and morphogenesis. Current Opinion in Genetics and Development 14 582-590.

Matsuoka H, Nagaya M, Tsukikawa S, Yanagi Y, Isogai A \& Kubota S 2006 Repeated hepatic intra-arterial chemotherapy based on results of anticancer drug sensitivity test in patients with synchronous hepatic metastases from colorectal cancer. Surgery 140 387-395.

Michalopoulos GK \& DeFrances MC 1997 Liver regeneration. Science 276 60-66.

Miyamoto T, Iwasaki H, Reizis B, Ye M, Graf T, Weissman IL \& Akashi K 2002 Myeloid or lymphoid promiscuity as a critical step in hematopoietic lineage commitment. Developmental Cell 3 137-147.

Nagaya M, Kubota S, Suzuki N, Akashi K \& Mitaka T 2006 Thermoreversible gelation polymer induces the emergence of hepatic stem cells in the partially injured rat liver. Hepatology 43 1053-1062.

Noguchi H, Xu G, Matsumoto S, Kaneto H, Kobayashi N, Bonner-Weir S \& Hayashi S 2006 Induction of pancreatic stem/progenitor cells into insulinproducing cells by adenoviral-mediated gene transfer technology. Cell Transplantation 15 929-938.

Rajagopal J, Anderson WJ, Kume S, Martinez OI \& Melton DA 2003 Insulin staining of ES cell progeny from insulin uptake. Science 299363.

Rausa F, Samadani U, Ye H, Lim L, Fletcher CF, Jenkins NA, Copeland NG \& Costa RH 1997 The cut-homeodomain transcriptional activator HNF-6 is coexpressed with its target gene HNF-3 beta in the developing murine liver and pancreas. Developmental Biology 192 228-246.

Ricordi C \& Strom TB 2004 Clinical islet transplantation: advances and immunological challenges. Nature Reviews. Immunology 4 259-268.

Sapir T, Shternhall K, Meivar-Levy I, Blumenfeld T, Cohen H, Skutelsky E, Eventov-Friedman S, Barshack I, Goldberg I, Pri-Chen S et al. 2005 Cellreplacement therapy for diabetes: Generating functional insulin-producing tissue from adult human liver cells. PNAS 102 7964-7969.
Shapiro AMJ, Lakey JRT, Ryan EA, Korbutt GS, Toth EL, Warnock GL, Kneteman NM \& Rajotte RV 2000 Islet transplantation in seven patients with type 1 diabetes mellitus using a glucocorticoid free immunosuppressive regimen. New England Journal of Medicine 343 230-238.

Sumazaki R, Shiojiri N, Isoyama S, Masu M, Keino-Masu K, Osawa M, Nakauchi H, Kageyama R \& Matsui A 2004 Conversion of biliary system to pancreatic tissue in Hes1-deficient mice. Nature Genetics 36 83-87.

Tang DQ, Lu S, Sun YP, Rodrigues E, Chou W, Yang C, Cao LZ, Chang LJ \& Yang LJ 2006 Reprogramming liver-stem WB cells into functional insulin-producing cells bypersistent expression of Pdx1and Pdx1-VP16 mediated by lentiviral vectors. Laboratory Investigation $\mathbf{8 6}$ 83-93.

Teitelman G, Alpert S, Polak JM, Martinez A \& Hanahan D 1993 Precursor cells of mouse endocrine pancreas coexpress insulin, glucagon and the neuronal proteins tyrosine hydroxylase and neuropeptide $\mathrm{Y}$, but not pancreatic polypeptide. Development 118 1031-1039.

Wiebe PO, Kormish JD, Roper VT, Fujitani Y, Alston NI, Zaret KS, Wright CV, Stein RW \& Gannon M 2007 Ptf1a binds to and activates area III, a highly conserved region of the Pdx1 promoter that mediates early pancreas-wide Pdx1 expression. Molecular and Cellular Biology 27 4093-4104.

Wilson ME, Scheel D \& German MS 2003 Gene expression cascades in pancreatic development. Mechanisms of Development 120 65-80.

Xu X, D’Hoker J, Stangé G, Bonné S, De Leu N, Xiao X, Van De Casteele M, Mellitzer G, Ling Z, Pipeleers D et al. 2008 Beta cells can be generated from endogenous progenitors in injured adult mouse pancreas. Cell 132 197-207.

Yang L, Li S, Hatch H, Ahrens K, Cornelius JG, Petersen BE \& Peck AB 2002 In vitro trans-differentiation of adult hepatic stem cells into pancreatic endocrine hormone-producing cells. PNAS 99 8078-8083.

Zalzman M, Anker-Kitai L \& Efrat S 2005 Differentiation of human liverderived, insulin-producing cells toward the beta-cell phenotype. Diabetes $\mathbf{5 4}$ 2568-2575.

Zaret KS 2008 Genetic programming of liver and pancreas progenitors: lessons for stem-cell differentiation. Nature Reviews. Genetics 9 329-340.

Received in final form 8 January 2009

Accepted 23 January 2009

Made available online as an Accepted Preprint 23 January 2009 